\title{
Regimen Used to Treat Plasma Cell Myeloma
}

National Cancer Institute

\section{Source}

National Cancer Institute. Regimen Used to Treat Plasma Cell Myeloma. NCI Thesaurus.

Code C63496.

Any regimen that can be used for the treatment of plasma cell myeloma. 